\title{
The effect of temperature on low-cycle fatigue of shape memory alloy
}

\author{
V. Iasnii, P. Yasniy, D. Baran \\ Faculty of Engineering of Machines, Structures and Technologies, Ternopil Ivan Puluj National Technical University, Ternopil, \\ Ukraine \\ v_iasnii@tntu.edu.ua, bttps://orcid.org/0000-0002-5768-5288 \\ petroyasniy@gmail.com, bttps://orcid.org/0000-0002-1928-7035 \\ jaturonkabat@gmail.com, bttps:// orcid.org/0000-0002-2067-8164
}

\author{
A. Rudawska \\ Faculty of Mechanical Engineering, Lublin University of Technology, Lublin, Poland \\ a.rudawska@pollub.pl, https://orcid.org/0000-0003-3592-8047
}

\begin{abstract}
The influence of temperature on the fatigue properties of pseudoelastic NiTi under low-cycle fatigue are investigated. Tests were performed under the uniaxial tensile deformation (pull-pull) at $0^{\circ} \mathrm{C}$ and $20^{\circ} \mathrm{C}$ which is above the austenite finish temperature. Experimental results indicate that the fatigue life of $\mathrm{NiTi}$ alloy increases with the decrease of test temperature from $20^{\circ} \mathrm{C}$ to $0^{\circ} \mathrm{C}$ in the case of presenting the results depending on the strain range and dissipated energy. Regardless the test temperature, with the increase of number of cycles to failure, the stress and strain ranges, as well as the dissipation energy decrease, and the total dissipation energy and Odqvist's parameter increase. The slope of the fatigue curves of NiTi alloy is greater at the temperature of $0^{\circ} \mathrm{C}$ in comparison with the $20^{\circ} \mathrm{C}$ in the case of employing the stress range, strain range, Odqvist's parameter, and total dissipation energy as the failure criteria, and is less while employing the dissipation energy as the failure criterion.
\end{abstract}

KEYwORDS. Pseudoelsticity; NiTi alloy; Low-cycle fatigue; Odqvist's parameter; Dissipated energy.

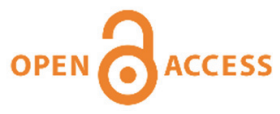

Citation: Iasnii, V., Yasniy, P., Baran, D., Rudawska, A., The effect of temperature on low-cycle fatigue of shape memory alloy, Frattura ed Integrità Strutturale, 50 (2019) $310-318$.

Received: 26.07.2019

Accepted: 19.08.2019

Published: 01.10.2019

Copyright: (C) 2019 This is an open access article under the terms of the CC-BY 4.0, which permits unrestricted use, distribution, and reproduction in any medium, provided the original author and source are credited.

\section{INTRODUCTION}

$\mathrm{U}$

nlike traditional structural materials, shape memory alloys (SMA) are characterized not only by mechanical and operational properties but also by functional ones. The functional properties of SMA include shape memory effect and the pseudoelasticity. Typical stress-strain curve of pseudoelastic SMAs above the austenite finish temperature shows a large hysteresis loop during loading and unloading. The hysteretic behaviour results in a high dissipation energy and stored strain energy which ensure high performance of SMA as a material for damping and storing the energy. 
The application of SMAs depends on the phase transformation temperatures, mechanical and functional properties, type of loading (static, cyclic and thermo-mechanical).

SMA are increasingly used in machine parts, implants $[1,2]$. Due to the high ability to energy dissipation, SMA are used in damping devices for civil engineering [3-6] or other structural elements [7, 8]. As they are subjected to intense cyclic loading during operation, it is important to ensure their reliability and lifetime under low-cycle fatigue [9].

Defects, such as internal subsurface voids, surface scratches which lead to crack initiation, play significant role under lowcycle fatigue [10].

Also, fatigue microcracks can initiate at the martensite-martensite or austenite-martensite interfaces [11]. The martensitemartensite or austenite-martensite interface motion causes the formation of defects in the grain, these defects becoming potential crack initiation areas. Cracks can initiate at the grain boundaries [12].

The cyclical loading affects not only the ability of the material to resist structural fatigue, but also the functional properties. Therefore, it is necessary to know how their functional and structural properties change in order to design reliably the devices and structural elements made of pseudoelastic SMA which operate under fatigue loading. It is also important to take into account the balance between structural and functional fatigue.

Under a cyclic loading the residual strain [13] increases and the dissipation energy reduces, thus worsening the efficiency of the damping devices [14]. Residual martensite plates increase with the number of cycles and are considered to be one of the causes of the formation of a residual strain during cyclic loading [15].

Lifetime of SMA can be predicted by stress- [16, 10], strain- [17-19] and energy based criteria [10] of fatigue failure. An overview of the structural fatigue of SMA under mechanical and thermomechanical loading is presented, for instance in the paper [20].

For low - cycle fatigue the strain amplitude and the number of cycles to failure could be represented by the empirical dependence

$$
\Delta \varepsilon N_{f}^{\beta}=\alpha
$$

where $\alpha$ and $\beta$ represent $\varepsilon_{a}$ in $N_{f}=1$ and the slope of the $\log \Delta \varepsilon-\log N_{f}$ curve, respectively.

For NiTi wire of $0.5 \mathrm{~mm}$ in diameter under rotating-bending fatigue test the relationship between $\alpha$ and $\mathrm{T}$ is expressed by the following equation [21]:

$$
\alpha=\alpha_{s} 10^{-a\left(T-M_{s}\right)}
$$

where $\mathrm{T}$ is test temperature; $M_{s}-$ martensite start temperature.

Based on the experimental results, the coefficients are determined as $\beta=0.28, \alpha_{\mathrm{s}}=0.248, \mathrm{a}=0.0032 \mathrm{~K}^{-1}[21]$.

For NiTi tube with outer diameter of $0.9 \mathrm{~mm}$ and inner $0.7 \mathrm{~mm}$ under rotating-bending fatigue test the dependence of $\alpha$ on $\mathrm{T}$ is expressed by the following equation [21]:

$$
\alpha=\frac{m}{\left(T-T_{0}\right)^{n}}+\alpha_{0}
$$

Based on the experimental results, the coefficients are determined as $\beta=0.25, m=0.065 \mathrm{~K}^{n}, n=0.4, \mathrm{~T}_{0}=297 \mathrm{~K}, \alpha_{0}=0.057$. A quasi-linear dependence of $\log \Delta W_{d i s}$ on $\log N_{f}$ for several values of the mean stress. It is, hence, interesting to approximate experimental results using the following curve [22]:

$$
\Delta W_{d i s}=\alpha_{1} N_{f}^{\beta_{1}}
$$

where $\Delta W_{d i s}-$ is dissipation energy per cycle; $\alpha$ and $\beta$ are material parameters.

Numerical results are in good agreement with experimental data for $\alpha=11$ and $\beta=-0.377$.

A damage based fatigue failure model by dividing the total damage sources into three parts, i.e., microcrack initiation, microcrack propagation and martensite transformation induced damage was proposed by Song [23]. The damage variable as the ratio of the accumulated dissipation energy after a prescribed number of cycles to that obtained at the failure life was defined 


$$
D=\sum_{i=1}^{N} W_{i} / \sum_{i=1}^{N_{f}} W_{i}
$$

where $W_{i}$ is the dissipation energy at $i$-th loading cycle.

So it is important to study the influence of temperature, above the austenite finish temperature, on structural fatigue of pseudoelastic NiTi alloy.

\section{EXPERIMENTAL SETUP AND MATERIAL}

7 he influence of temperature $\left(\right.$ at $0{ }^{\circ} \mathrm{C}$ and $20^{\circ} \mathrm{C}$ ) on structural fatigue was studied on pseudoelastic Ni55.8Ti44.2 alloy. Characteristics of thermal transitions during SMA phase transformations were investigated using Differential Scanning Calorimetry (DSC) by DSC Q1000 TAI [24]. Austenite finish temperature is $A_{f}=-38.7^{\circ} \mathrm{C}$.

Material has the following mechanical properties at $0^{\circ} \mathrm{C}$ and $20^{\circ} \mathrm{C}$ : yield strength, $\sigma_{0.2}=447 \mathrm{MPa}$ and $523 \mathrm{MPa}$, ultimate tensile strength, $\sigma_{\text {UTS }}=869 \mathrm{MPa}$ and $780 \mathrm{MPa}[24,25]$. The chemical composition of the alloy according to the delivered certificate is as follows: $55.78 \% \mathrm{Ni} ; 0.005 \% \mathrm{Co} ; 0.005 \% \mathrm{Cu} ; 0.005 \% \mathrm{Cr} ; 0.012 \% \mathrm{Fe} ; 0.005 \% \mathrm{Nb} ; 0.032 \% \mathrm{C} ; 0.001 \% \mathrm{H}$; $0.04 \% \mathrm{O} ; 0.001 \% \mathrm{~N}$ and $44.12 \% \mathrm{Ti}$.

Cylindrical specimens with a diameter of $4 \mathrm{~mm}$ and gage length of $12.5 \mathrm{~mm}$, machined from rod $8 \mathrm{~mm}$ in diameter, were tested under uniaxial cyclic loading at temperature $0^{\circ} \mathrm{C}$ and $20^{\circ} \mathrm{C}$ at stress ratio $R=\sigma_{\min } / \sigma_{\max }=0$ (here $\sigma_{\min }$ and $\sigma_{\max }$ are the minimum and maximum stresses) on the servo-hydraulic machine STM-10 [26] with automated control and data acquisition system under sinusoidal load with a frequency of $0.5 \mathrm{~Hz}$.

Fatigue tests were carried out under displacement-controlled mode at $0^{\circ} \mathrm{C}$. In this case, the maximum stress, except for the first twenty loading cycles, remains constant [24]. Therefore, it can be assumed that the stress range was constant during the testing (the stress range was changed less than 3\%). Fatigue tests were carried out under stress-controlled mode at $20^{\circ} \mathrm{C}$.

Longitudinal strain was measured by Bi-06-308 extensometer produced by Bangalore Integrated System Solutions (BISS), maximum error did not exceed $0.1 \%$. The crosshead displacement was determined by inductive Bi-02-313 sensor with an error not more than $0.1 \%$. The tests at $0^{\circ} \mathrm{C}$ were carried out in the chamber filled with ice and ice water. This provided the constant temperature of $0^{\circ} \mathrm{C}$ measured by chromel-alumel thermocouple mounted on the sample with an error not more than $0.5^{\circ} \mathrm{C}$.

A literature review [24] shows that water have not significant influence on fatigue behaviour of NiTi alloys [21, 27-29].

\section{RESULTS AND DISCUSSION}

$\checkmark$ he dependences of the stress range $\Delta \sigma$ on the number of cycles to failure $N_{f}$ for NiTi alloy in ice water at $0^{\circ} \mathrm{C}$ and at $20^{\circ} \mathrm{C}$ in the air are shown in Fig. 1. Stress range was determined at the number of half-cycles to failure.

Experimental data under low-cycle fatigue presented on Fig. 1, are plotted according to the failure criterion of the specimen, and could be well-enough described by power function

$$
\Delta \sigma \cdot N_{f}^{\beta_{\sigma}}=\alpha_{\sigma}
$$

The parameters $\alpha_{\sigma}$ and $\beta_{\sigma}$ in Eqn. (6), that were determined by fitting of experimental data (Fig. 1), are given in Tab. 1. The increase of testing temperature from 0 to $20^{\circ} \mathrm{C}$ increases the fatigue lifetime under low-cycle fatigue at $N_{f}>1000$ cycles and decreases the angle of relationship between $\lg \Delta \sigma$ and $\lg N_{f}$. A similar effect of testing temperature $(323 \mathrm{~K}, 333 \mathrm{~K})$ on the fatigue lifetime was found for Ti $50.7 \mathrm{at} \% \mathrm{Ni}$ alloy [30].

Fig. 2 shows experimental fatigue curves in coordinates strain range versus number of cycles to failure of the specimen. The strain range values were determined at the number of half-cycles to failure, in the same way as stress range. The experimental data were fitted by means of Eqn. (1) with the determined parameters, which are given in Tab. 1.

The linear behavior of the dependence of the strain amplitude on the number of cycles to failure under low-cycle fatigue at different ratios between the test temperature and the austenite finish temperature, is confirmed by the results obtained by the authors [31-33].

In contrast to the data presented in Fig. 1, using strain range as a criterion of fatigue failure, fatigue lifetime of pseudoelastic $\mathrm{Ni}_{55.8} \mathrm{Ti}_{44.2}$ alloy at $20^{\circ} \mathrm{C}$ is significantly lower than at $0^{\circ} \mathrm{C}$. Moreover, the slope angle of both curves in logarithmic scales is 
approximately the same (parameter $\beta$ in Tab. 1). Such effect of temperature on low-cycle fatigue lifetime are similar for NiTi wire of $0.5 \mathrm{~mm}$ in diameter and NiTi tube with outer diameter of $0.9 \mathrm{~mm}$ and inner $0.7 \mathrm{~mm}$ under rotating-bending fatigue test at temperatures $20^{\circ} \mathrm{C}-80^{\circ} \mathrm{C}$ [21]. Fatigue lifetime increase with the decrease in temperature from $383 \mathrm{~K}$ to $293 \mathrm{~K}$ for 3 kinds of Ti-Ni base shape memory alloy wires with the compositions of $\mathrm{Ti}-50.0 \mathrm{at} \% \mathrm{Ni}$, Ti- $50.5 \mathrm{at} \% \mathrm{Ni}$ and $50.85 \mathrm{at} \% \mathrm{Ni}$, respectively under rotary bending fatigue tests [19]. This was observed for wires with diameter of $1.0 \mathrm{~mm}$.

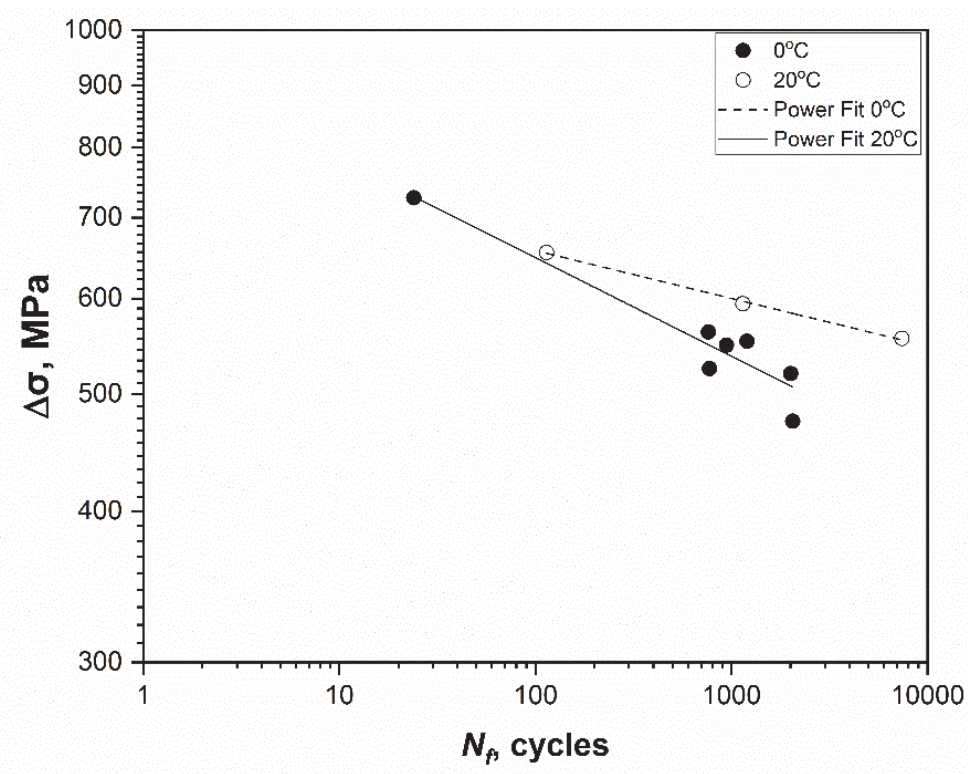

Figure 1: Dependence of the stress range on the number of loading cycles in ice water at $0^{\circ} \mathrm{C}$ and at $20^{\circ} \mathrm{C}$ in the air.

The fatigue life was estimated using the Odqvist's parameter, which characterizes the accumulated plastic strain $\Delta \varepsilon_{p}$, and under uniaxial cyclic loading is determined by formula [34]

$$
\chi=2 N \cdot \Delta \varepsilon_{p}
$$

where $N$ is the numbers of loading cycles.

\begin{tabular}{|c|c|c|c|c|c|c|c|c|c|}
\hline $\mathrm{T},{ }^{\circ} \mathrm{C}$ & $\alpha$ & $\begin{array}{c}\beta \\
\text { Eq. (1) }\end{array}$ & $R^{2}$ & $\alpha_{\sigma}$ & $\begin{array}{c}\beta_{\sigma} \\
\text { Eq. (6) }\end{array}$ & $R^{2}$ & $A$ & $\begin{array}{c}B \\
\text { Eq. (9) }\end{array}$ & $R^{2}$ \\
\hline 0 & $\begin{array}{c}8.754 \\
\pm 1.339\end{array}$ & $\begin{array}{c}0.14 \\
\pm 0.026\end{array}$ & 0.868 & $\begin{array}{c}943.7 \\
\pm 53.84\end{array}$ & $\begin{array}{c}0.0814 \\
\pm 0.00898\end{array}$ & 0.933 & 2.472 & 0.0581 & 0.941 \\
\hline 20 & $\begin{array}{c}5.379 \\
\pm 1.634 \\
\end{array}$ & $\begin{array}{l}0.198 \\
\pm 0.05\end{array}$ & 0.944 & $\begin{array}{r}788.6 \\
\pm 10.56 \\
\end{array}$ & $\begin{array}{c}0.0396 \\
\pm 0.00195\end{array}$ & 0.997 & 3.018 & 0.0205 & 0.999 \\
\hline
\end{tabular}

Table 1: Equations parameters for Ni55.8Ti44.2 alloy

Replacing $N$ in Eqn. (7) on $N_{\mathrm{f}}$ and taking into account that for the SMA the plastic strain range can be replaced by the expansion of the elastic deformation $\Delta \varepsilon$, the formula (7) can be rewritten as follows:

$$
\chi=2 N \cdot \Delta \varepsilon
$$

In the Eqn. (8), the strain range $\Delta \varepsilon$ was determined in the same way (at $N=0.5 N_{f}$ ) as in the previous cases.

According to the Fig. 3, the Odqvist's parameter increases linearly proportional to the number of loading cycles before the failure of the specimen and is well described by the dependence

$$
\chi_{f}=A+B \cdot N_{f}
$$


The constant values (Tab. 1) of the Eqn. (9) were determined by the approximation of the experimental data using the least squares method. Analysis of the experimental dependencies in Fig. 3 shows that Odqvist's parameter $\chi_{f}$, before failure of material, increase with the decrease in temperature from 20 to $0^{\circ} \mathrm{C}$. Moreover, the Odqvist's parameter at both temperatures $0^{\circ} \mathrm{C}$ and $20^{\circ} \mathrm{C}$ significantly increase with the increase in loading cycles. It implies from the analysis of experimental dependencies, presented on Fig. 3, that the value of Odqvist's parameter before the fatigue failure of material $\chi_{f}$ is increasing with the decrease of temperature from $20^{\circ} \mathrm{C}$ to $0^{\circ} \mathrm{C}$. Also, with the increase of number of loading cycles the ratio of Odqvist's parameter at $0^{\circ} \mathrm{C}$ and $20^{\circ} \mathrm{C}$ increases significantly.

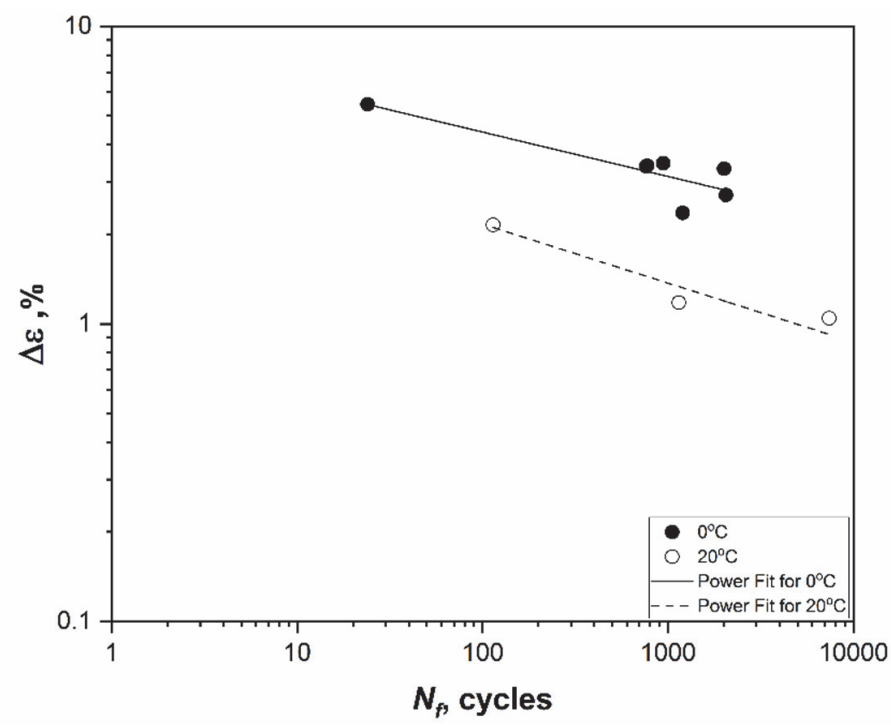

Figure 2: Dependence of the strain range on the number of loading cycles in ice water at $0^{\circ} \mathrm{C}$ and at $20^{\circ} \mathrm{C}$ in the air.

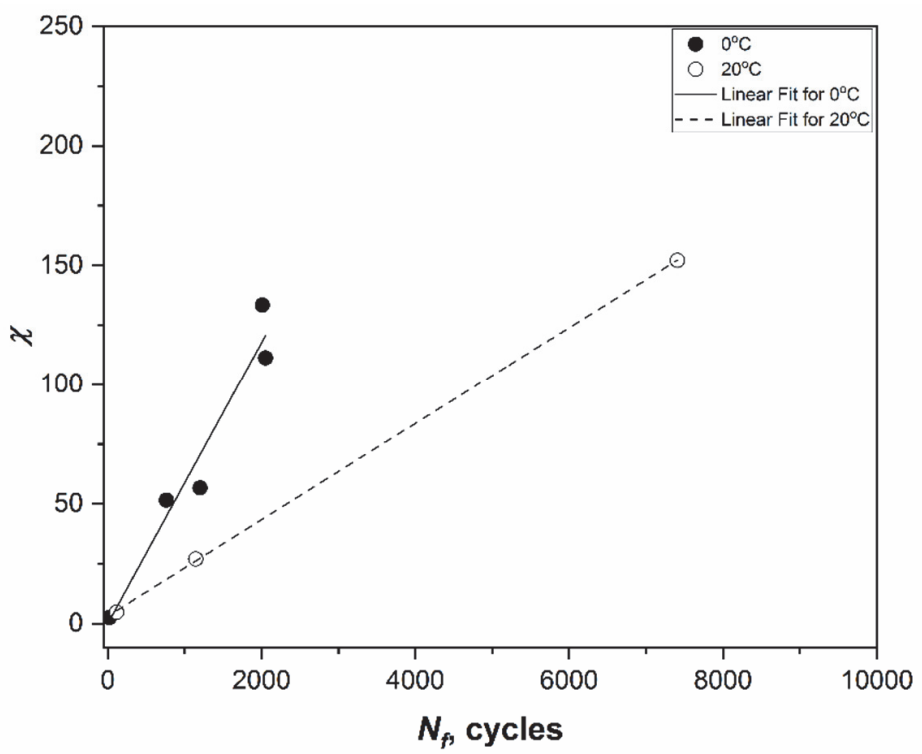

Figure 3: Dependence of the Odqvist's parameter on the number of loading cycles in ice water at $0^{\circ} \mathrm{C}$ and at $20^{\circ} \mathrm{C}$ in the air.

With the increasing of cycles to failure the dissipated energy per cycle decreases (Fig. 4). Experimental data in this case are well described by the logarithmic dependence

$$
\Delta W_{d i s} \cdot N_{f}^{\beta_{\Delta W}}=\alpha_{\Delta W}
$$




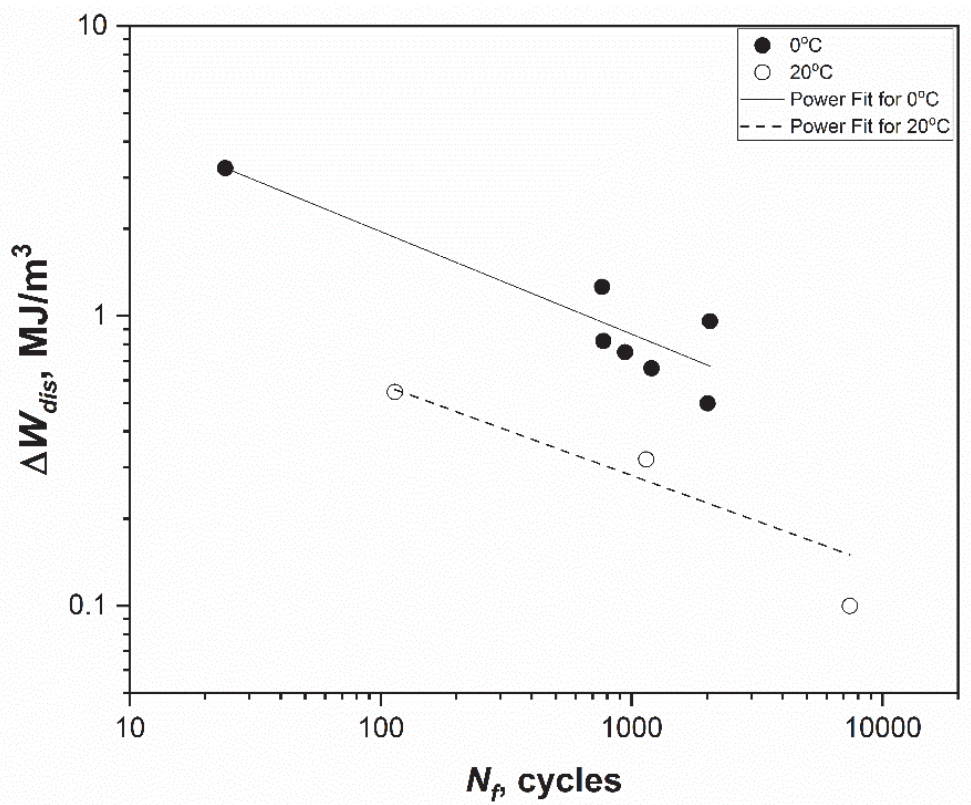

Figure 4: Dependence of the dissipated energy on the number of loading cycles in ice water at $0^{\circ} \mathrm{C}$ and at $20^{\circ} \mathrm{C}$ in the air.

The constant values $\alpha_{\Delta W}$ and $\beta_{\Delta W}$ of the Eqn. (10) were determined by the approximation of the experimental data using the least squares method are presented in Tab. 2.

\begin{tabular}{|c|c|c|c|c|c|c|}
\hline $\mathrm{T},{ }^{\circ} \mathrm{C}$ & $\alpha_{\Delta W}$ & $\begin{array}{c}\beta_{\Delta W} \\
\text { Eq. (10) }\end{array}$ & $R^{2}$ & $A_{W}$ & $\begin{array}{c}B_{W} \\
\text { Eq. (13) }\end{array}$ & $R^{2}$ \\
\hline 0 & $\begin{array}{c}9.974 \\
\pm 1.604\end{array}$ & $\begin{array}{c}0.3537 \\
\pm 0.0351\end{array}$ & 0.950 & 142.6 & 0.663 & 0.709 \\
\hline 20 & $\begin{array}{c}2.478 \\
\pm 1.253\end{array}$ & $\begin{array}{l}0.3148 \\
\pm 0.092\end{array}$ & 0.949 & 148.4 & 0.0925 & 0.924 \\
\hline
\end{tabular}

Table 2: Equations parameters for Ni55.8Ti44.2 alloy.

In the Eqn. (10), the energy of dissipation was determined in the same way as in the previous cases at the number of halfcycles to failure. The fatigue life of the NiTi alloy increases with the decrease in test temperature when using the strain range (Fig. 2), as well as dissipated energy (Fig.4).

The influence of testing temperature on accumulated dissipation energy before failure was analysed. The accumulated dissipation energy was determined by formula

$$
W_{d i s}=\sum_{i=1}^{N_{f}} \Delta W_{i}
$$

where $\Delta W_{i}$ is the dissipated energy for $i$-th loading cycle.

As the first approximation, the change in the area of hysteresis loop during first cycles could be neglected. In this case, the formula (11) can be rewritten as follows:

$$
W_{d i s}=\Delta W_{d i s} \cdot N_{f}
$$

where $\Delta W_{\text {dis }}$ is the dissipated energy at mean lifetime $N_{f}$.

As in the case with Odqvist's parameter, the experimental values of total dissipated energy could be described by a linearly proportional dependence on cycles to failure 


$$
W_{d i s}=A_{W}+B_{W} \cdot N_{f}
$$

The parameters (Tab. 2) of the Eqn. (13) were determined by the approximation of the experimental data using the least squares method.

Therefore (Fig. 5), the total dissipation energy is not constant, but increases with the increasing number of loading cycles to specimen failure.

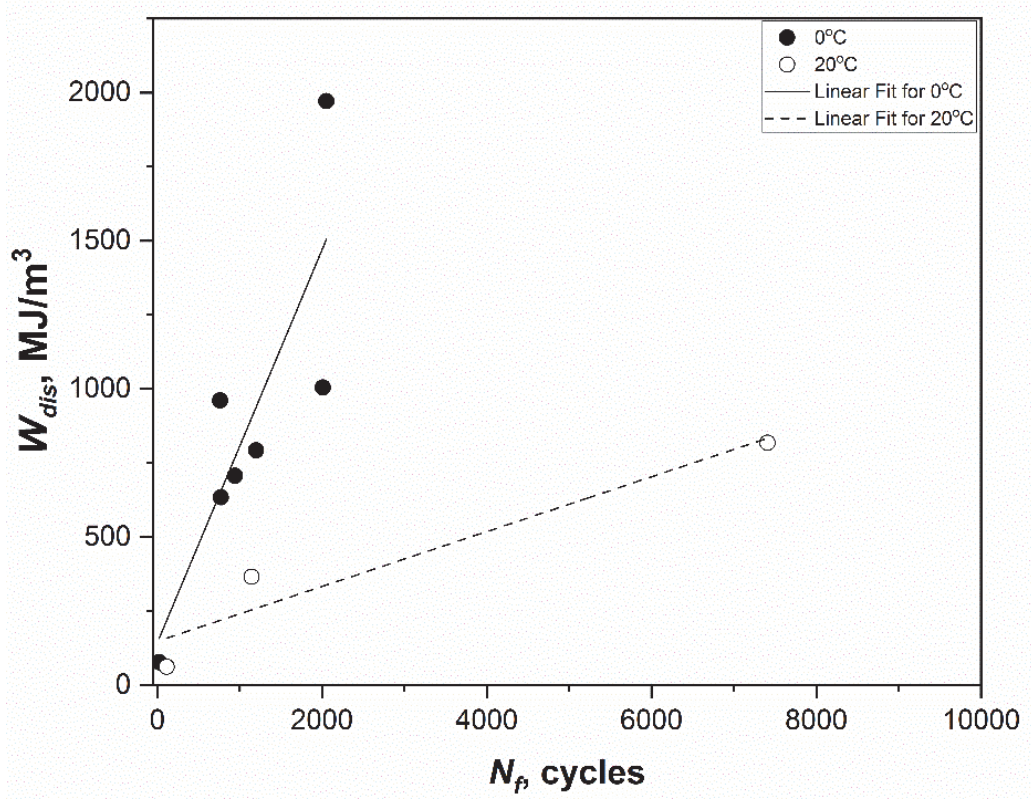

Figure 5: Dependence of the total dissipation energy on the number of loading cycles in ice water at $0^{\circ} \mathrm{C}$ and at $20^{\circ} \mathrm{C}$ in the air.

The fatigue life of NiTi alloy increases with the decrease in test temperature when using the strain range (Fig. 2), as well as dissipated energy (Fig. 4).

\section{CONCLUSIONS}

1. Low-cycle fatigue of pseudoelastic Ni55.8Ti44.2 shape memory alloy was studied under the uniaxial tensile deformation at temperature of $0^{\circ} \mathrm{C}$ and $20^{\circ} \mathrm{C}$, which is above the austenite finish temperature $\left(A_{f}=-38.7^{\circ} \mathrm{C}\right)$. Fatigue tests were carried out on cylindrical specimens under displacement-controlled mode at $0^{\circ} \mathrm{C}$ and under stress-controlled mode at $20^{\circ} \mathrm{C}$. The fatigue life was described by stress, strain and energy failure criteria.

2. The fatigue life of NiTi alloy increases with the decrease of test temperature from $20^{\circ} \mathrm{C}$ to $0^{\circ} \mathrm{C}$ in the case of presenting the results depending on the strain range and dissipated energy. Nevertheless, in the case of employing the stress range, the Odqvist's parameter or the total dissipation energy, and the lifetime of NiTi alloy under the low temperature in the medium of distilled ice water is less comparing with the room temperature.

3. Regardless the test temperature, with the increase of number of cycles to failure, the stress and strain ranges, as well as the dissipation energy decrease, and the total dissipation energy and Odqvist's parameter increase.

4. Therefore, as in the case of traditional structural elements, the total dissipation energy of the low-cycle fatigue is not constant and increases proportionally to the increase of cycles number to failure. It is obvious, that if the energy of fatigue failure is constant, then the dissipation energy is wasted not only for the formation of fatigue damage, but also on the heating of specimen, as well as on the forward and reverse phase transformations during the cyclic loading.

5. The slope of the fatigue lifetime curves of $\mathrm{NiTi}$ alloy to the $O X$ axis is greater at the temperature of $0^{\circ} \mathrm{C}$ in comparison with the $20^{\circ} \mathrm{C}$ in the case of employing the stress range, strain range, Odqvist's parameter and total dissipation energy as the failure criteria, and is less while employing the dissipation energy as the failure criterion. 


\section{REFERENCES}

[1] Auricchio, F., Boatti, E., Conti, M. (2015). SMA Biomedical Applications, Shape Mem. Alloy Eng., pp. 307-331. DOI: 10.1016/B978-0-08-099920-3.00011-5.

[2] Morgan, N.B. (2004). Medical shape memory alloy applications - The market and its products, Mater. Sci. Eng. A, 378(12 SPEC. ISS.), pp. 16-23. DOI: 10.1016/j.msea.2003.10.326.

[3] Ozbulut, O.E., Hurlebaus, S., Desroches, R. (2011). Seismic response control using shape memory alloys: A review, J. Intell. Mater. Syst. Struct., 22(14), pp. 1531-1549. DOI: 10.1177/1045389X11411220.

[4] Yasniy, P., Kolisnyk, M., Kononchuk, O., Iasnii, V. (2017). Calculation of constructive parameters of SMA damper, Sci. J. TNTU, 88(4), pp. 7-15.

[5] Torra, V., Auguet, C., Carreras, G., Dieng, L., Lovey, F.C., Terriault, P. (2012). The SMA: An Effective Damper in Civil Engineering that Smoothes Oscillations, Mater. Sci. Forum, 706-709(July 2015), pp. 2020-2025.

DOI: $10.4028 /$ www.scientific.net/MSF.706-709.2020.

[6] Isalgue, A., Lovey, F.C., Terriault, P., Martorell., Torra, F.R.M., Torra, V. (2006). SMA for Dampers in Civil Engineering, Mater. Trans., 47(3), pp. 682-690. DOI: 10.2320/matertrans.47.682.

[7] Menna, C., Auricchio, F., Asprone, D. (2015). Applications of shape memory alloys in structural engineering, Shape Memory Alloy Engineering, Elsevier.

[8] Mohd Jani, J., Leary, M., Subic, A., Gibson, M.A. (2014). A review of shape memory alloy research, applications and opportunities, Mater. Des., 56, pp. 1078-1113. DOI: 10.1016/j.matdes.2013.11.084.

[9] Eggeler, G., Hornbogen, E., Yawny, A., Heckmann, A., Wagner, M. (2004). Structural and functional fatigue of NiTi shape memory alloys, Mater. Sci. Eng. A, 378(1-2 SPEC. ISS.), pp. 24-33. DOI: 10.1016/j.msea.2003.10.327.

[10] Predki, W., Klönne, M., Knopik, A. (2006). Cyclic torsional loading of pseudoelastic NiTi shape memory alloys: Damping and fatigue failure, Mater. Sci. Eng. A, 417(1-2), pp. 182-189. DOI: 10.1016/j.msea.2005.10.037.

[11] Miyazaki, S., Imai, T., Igo, Y., Otsuka, K. (1986). Effect of cyclic deformation on the pseudoelasticity characteristics of Ti-Ni alloys, Metall. Trans. A, 17(1), pp. 1115-1120. DOI: 10.1007/BF02644447.

[12] Gloanec, A.L., Cerracchio, P., Reynier, B., Van Herpen, A., Riberty, P. (2010). Fatigue crack initiation and propagation of a TiNi shape memory alloy, Scr. Mater., 62(10), pp. 786-789. DOI: 10.1016/j.scriptamat.2010.02.001.

[13] Kan, Q., Yu, C., Kang, G., Li, J., Yan, W. (2016). Experimental observations on rate-dependent cyclic deformation of super-elastic NiTi shape memory alloy, Mech. Mater., 97, pp. 48-58. DOI: 10.1016/j.mechmat.2016.02.011.

[14] Pan, Q., Cho, C. (2008). Damping property of shape memory alloys, Metal, pp. 1-5.

[15] Miyazaki, S., Mizukoshi, K., Ueki, T., Sakuma, T., Liu, Y. (1999). Fatigue life of Ti-50 at.\% Ni and Ti-40Ni-10Cu (at.\%) shape memory alloy wires, Mater. Sci. Eng. A, 273-275, pp. 658-663. DOI: 10.1016/S0921-5093(99)00344-5.

[16] Scirè Mammano, G., Dragoni, E. (2012). Functional fatigue of NiTi shape memory wires for a range of end loadings and constraints, Frat. Ed Integrita Strutt., 23, pp. 25-33. DOI: 10.3221/IGF-ESIS.23.03.

[17] Matsui, R., Makino, Y., Tobushi, H., Furuichi, Y., Yoshida, F. (2006). Influence of Strain Ratio on Bending Fatigue Life and Fatigue Crack Growth in TiNi Shape-Memory Alloy Thin Wires, Mater. Trans., 47(3), pp. 759-765. DOI: 10.4028/www.scientific.net/KEM.340-341.1193.

[18] Casciati, F., Casciati, S., Faravelli, L. (2007). Fatigue characterization of a Cu-based shape memory alloy, Proc. Est. Acad. Sci. - Phys. Math., 56(2), pp. 207-217.

[19] Kim, Y. (2002). Fatigue Properties of the Ti-Ni Base Shape Memory Alloy Wire, Mater. Trans., 43(7), pp. 1703-1706, DOI: $10.2320 /$ matertrans.43.1703.

[20] Kang, G., Song, D. (2015). Review on structural fatigue of NiTi shape memory alloys: Pure mechanical and thermomechanical ones, Theor. Appl. Mech. Lett., 5(6), pp. 245-254. DOI: 10.1016/j.taml.2015.11.004.

[21] Matsui, R., Tobushi, H., Furuichi, Y., Horikawa, H. (2004). Tensile Deformation and Rotating-Bending Fatigue Properties of a Highelastic Thin Wire, a Superelastic Thin Wire, and a Superelastic Thin Tube of NiTi Alloys, J. Eng. Mater. Technol., 126(4), pp. 384-391. DOI: 10.1115/1.1789952.

[22] Moumni, Z., Zaki, W., Maitournam, H. (2009). Cyclic Behavior and Energy Approach to the Fatigue of Shape Memory Alloys, J. Mech. Mater. Struct., 4(2), pp. 395-411. DOI: 10.2140/jomms.2009.4.395.

[23] Song, D., Kang, G., Kan, Q., Yu, C., Zhang, C. (2015). Damage-based life prediction model for uniaxial low-cycle stress fatigue of super-elastic NiTi shape memory alloy microtubes, Smart Mater. Struct., 24(8), pp. 085007.

DOI: $10.1088 / 0964-1726 / 24 / 8 / 085007$.

[24] Iasnii, V., Yasniy, P., Lapusta, Y., Shnitsar, T. (2018). Experimental study of pseudoelastic NiTi alloy under cyclic loading, Sci. J. TNTU, 92(4), pp. 7-12. 
[25] Iasnii, V., Junga, R. (2018). Phase Transformations and Mechanical Properties of the Nitinol Alloy with Shape Memory, Mater. Sci., 54(3), pp. 406-411.

[26] Yasniy, P. V., Hlado, V.B., Hutsaylyuk, V.B., Vuherer, T. (2005). Microcrack initiation and growth in heat-resistant 15Kh2MFA steel under cyclic deformation, Fatigue Fract. Eng. Mater. Struct., 28(4), pp. 391-397. DOI: $10.1111 /$ j.1460-2695.2005.00870.x.

[27] Tobushi, H., Nakahara, T., Shimeno, Y., Al., E. (2000). Low cycle fatigue of TiNi shape memory alloy and formulation of fatigue life, J. Eng. Mater. Technol. ASME, 122(2), pp. 186-191. DOI: 10.1115/1.482785.

[28] Cheung, G.S., Shen, Y., Darvell, B.W. (2007). Effect of environment on low-cycle fatigue of a nickel-titanium instrument, J Endod, 33, pp. 1433-1437.

[29] Shen, Y., Qian, W., Abtin, H., Gao, Y., Haapasalo, M. (2012). Effect of environment on fatigue failure of controlled memory wire nickel-titanium rotary instruments., J. Endod., 38(3), pp. 376-380. DOI: 10.1016/j.joen.2011.12.002.

[30] Van Humbeeck, J. (1999). Non-medical applications of shape memory alloys, Mater. Sci. Eng. A, 273-275, pp. 134148. DOI: 10.1016/S0921-5093(99)00293-2.

[31] Melton, K.., Mercier, O. (1979). Fatigue of NITI thermoelastic martensites, Acta Metall., 27(1), pp. $137-144$. DOI: $10.1016 / 0001-6160(79) 90065-8$.

[32] Robertson, S.W., Pelton, A.R., Ritchie, R.O. (2012). Mechanical fatigue and fracture of Nitinol, Int. Mater. Rev., 57(1), pp. 1-37. DOI: 10.1179/1743280411Y.0000000009.

[33] Melton, K.N., Mercier, O. (1979). The effect of the martensitic phase transformation on the low cycle fatigue behaviour of polycrystalline Ni-Ti and Cu-Zn-Al alloys, Mater. Sci. Eng., 40(1), pp. 81-87. DOI: 10.1016/0025-5416(79)90010-7.

[34] Yasnii, P.V., Glad'o, V.B., Gutsailyuk, V.B. (2003). The Influence of Elastoplastic Deformation on the Dislocation Structure of 15Kh2MFA Steel, Strength Mater., 35(6), pp. 562-567. DOI: 10.1023/B:STOM.0000013606.21409.af. 